ISSN 1991-8631

Original Paper

http://indexmedicus.afro.who.int

\title{
Chemical and biological investigations of Syzygium aromaticum L. essential oil from Benin
}

\author{
Guy Alain ALITONOU ${ }^{1 *}$, Fidele Paul TCHOBO ${ }^{1}$, Félicien AVLESSI ${ }^{1}$, \\ Boniface YEHOUENOU ${ }^{1}$, Paul YEDOMONHAN ${ }^{2}$, Alain Yaya KOUDORO ${ }^{1}$ and \\ Chantal MENUT ${ }^{3}$, Dominique Koko SOHOUNHLOUE ${ }^{1}$ \\ ${ }^{1}$ Laboratoire d'Etude et de Recherche en Chimie Appliquée. 01 BP : 2009 Ecole Polytechnique d'Abomey- \\ Calavi, Université d'Abomey-Calavi, Bénin. \\ ${ }^{2}$ Département de Biologie Végétale, Faculté des Sciences et Technique de l'Université d'Abomey-Calavi, \\ Bénin. \\ ${ }^{3}$ Institut des Biomolécules Max Mousseron, Equipe Glycochimie, IBMM UMR 5247 CNRS-UM1-UM2, \\ ENSCM, 8 rue de l'Ecole Normale, 34296, Montpellier, France. \\ *Corresponding author, E-mail : alainguy20022002@yahoo.fr
}

\begin{abstract}
The essential oil obtained by hydrodistillation from seeds of Syzygium aromaticum (Myrtaceae) growing in Benin was analyzed by gas chromatography (GC) and gas chromatography-mass spectrometry (GC/MS). Twenty-one components, which represented $99.4 \%$ of the total constituents of the oil were identified. The essential oil is rich in hydrocarbons monoterpenic. The major constituents found were eugenol (60.4\%), trans- $\beta$-caryophyllene (24.0\%). The oil extract revealed an important antiradical activity and a high antimicrobial activity.

(C) 2012 International Formulae Group. All rights reserved.
\end{abstract}

Keywords: Antimicrobial activity, antiradical activity, essential oil, eugenol, trans- $\beta$-caryophyllene, Syzygium aromaticum.

\section{INTRODUCTION}

Syzigium aromaticum L. (syn. Eugenia caryophyllata L. Merr. \& Perry) are certain essential plant oils, widely used as fragrances and flavors in the perfumery and food (Murray, 2000). The exact geographical origin of the clove tree is unknown. It is probable that the tree originated in the warm and humid climate of tropical Asia, perhaps in the Mollucas.

The clove-producing areas are located on the islands of Ceylon and Penang as well as
Indonesia's Mollucas islands (Politeo et al., 2010). The essential oil obtained from the buds of this plant (clove oil) finds extensive use in dental formulations, toothpaste, breath freshener, mouthwashes, soaps, cosmetics items and insect repellent. The oil possesses antibacterial, antifungal, antioxidant and cytotoxic properties (Baratta et al., 1998; Dorman et al., 2000; Gayoso et al., 2005; Prashar et al., 2006; Politeo et al., 2010). Traditionaly for its medicinal properties (treatment of dental care, analgesic and 
antiseptic etc) (Cai and Wu, 1996), Syzygium aromaticum oil has been demonstrated to be effective in treating antifungal (Chami et al., 2005), antibacterial (Cai and Wu, 1996; Beuchat, 2000; Friedman et al., 2002; Kalemba and Kunicka, 2003), anticarcinogenic (Zheng et al., 1992), antiallergic (Kim et al., 1998), antimutagenic activity (Miyazawa and Hisama, 2001), analgesic, anesthetic, stimulating, stomach ache tonic, antiemetic, antiseptic, antispasmodic (Sellan, 2002; Lavabre, 1992).

On the chemical point of view, Politeo et al. (2010) identified eugenol $(80.5 \%)$ as the dominant volatile compound of the essential oil sample of dried clove buds from Croatia (Politeo et al., 2010).

The present study was designed to investigate the chemical composition and evaluate the antimicrobial, antiradical activities of this essential oil extracted from $S$. aromaticum seeds commonly used as food and in perfumery.

\section{MATERIALS AND METHODS Plant material}

The plant material was collected in the areas of Abomey-Calavi in Benin in June 2006. The sample was authenticated by the Pr. Akoegninou of the Herbarium of AbomeyCalavi University, Department of Vegetal Biology where voucher specimen [AA6417/HNB] was kept for future reference. Batches of $200 \mathrm{~g}$ of fresh seeds were submitted to hydrodistillation for $3 \mathrm{~h}$ using a Clevenger-type apparatus; after decantation the oils were dried using over anhydrous $\mathrm{Na}_{2} \mathrm{SO}_{4}$ sodium sulphate and stored in sealed vials below $10^{\circ} \mathrm{C}$ until using.

\section{Gas Chromatography-Mass Spectrometry}

The oils were analyzed on a Varian CP3380 GC equipped with a HP5 (100\% dimethylpolysiloxane) fitted with a fused silica capillary column (30 m x $0.25 \mathrm{~mm}$ i.d. film thickness $0.25 \mu \mathrm{m}$ ); temperature program $50-200{ }^{\circ} \mathrm{C}$ at $5{ }^{\circ} \mathrm{C} / \mathrm{min}$, injector temperature $220{ }^{\circ} \mathrm{C}$, detector temperature $250{ }^{\circ} \mathrm{C}$, carrier gas $\mathrm{N}_{2}$ at a flow rate of $0.5 \mathrm{~mL} \cdot \mathrm{min}^{-1}$. Diluted samples $(10 / 100, \mathrm{v} / \mathrm{v}$, in methylene chloride) of $2.0 \mu \mathrm{L}$ were injected manually in a split mode. The percentage compositions were obtained from electronic integration measurements without taking into account relative response factors. The linear retention indices of the components were determined relatively to the retention times of a series of $n$-alkanes $\left(\mathrm{C}_{9}-\mathrm{C}_{20}\right)$.

GC/MS analyses were performed using a Hewlett Packard apparatus equipped with a HP5 fused silica column (30 m x $0.25 \mathrm{~mm}$; film thickness $0.25 \mu \mathrm{m}$ ) and interfaced with a quadruple detector (Model 5970). Column temperature was programmed from $70^{\circ}$ to $200{ }^{\circ} \mathrm{C}$ at $10^{\circ} \mathrm{C} / \mathrm{min}$; injector temperature was $220{ }^{\circ} \mathrm{C}$. Helium was used as carrier gas at a flow rate of $0.6 \mathrm{~mL} \cdot \mathrm{min}^{-1}$, the mass spectrometer was operated at $70 \mathrm{eV}$. Diluted samples $(10 / 100, \mathrm{v} / \mathrm{v}$, in methylene chloride) of $2.0 \mu \mathrm{L}$ were injected manually in the split mode.

The identification of individual compounds was based on the comparison of their relative retention times with those of authentic samples on the HP5 column and by matching the linear retention indices and mass spectra of peaks with those obtained from authentic samples and/or the NBS75K.L and NIST98.L libraries spectra and published data (Adams, 2007; Joulain and König, 1998).

\section{Antiradical activity \\ Free radical scavenging activity: DPPH test}

Antiradical scavenging activity was determined using 1,1-diphenyl-2picrylhydrazyl (DPPH) following the Mellors and Tappel method (Mellors and Tappel, 1996), adapted to essential oil screening (Alitonou et al., 2010). 1,1-diphenylpicrylhydrazyl [1898-66-4] was purchased from Sigma-Aldrich chemistry and the solutions were prepared with analytical grade solvents purchased from standard commercial sources.

DPPH was dissolved in ethanol to give a $100 \mu \mathrm{M}$ solution. To $2.0 \mathrm{~mL}$ of the ethanolic solution of DPPH were added $100 \mu \mathrm{L}$ of a methanolic solution of the antioxidant reference eugenol at different concentrations. 
The essentials oils and the fractions were tested in the same manner. The control, without antioxidant, is represented by the DPPH ethanolic solution containing $100 \mu \mathrm{L}$ of methanol. The decrease in absorption was measured at $517 \mathrm{~nm}$ after $30 \mathrm{~min}$, at $30{ }^{\circ} \mathrm{C}$.

All measurements were performed in triplicate and the concentration required for $50 \%$ reduction $\quad(50 \%$ scavenging concentration $\mathrm{SC}_{50}$ ) was determined graphically. All the spectrophotometric measures were performed with a SAFAS UV mc2 spectrophotometer, equipped with a multicells/multikinetics measure system and with a thermostated cells-case.

The free radical-scavenging activity of each solution was then calculated according the following equation (Avlessi et al., 2005):

$$
S C \%=\frac{\text { Ablank-Asample }}{\text { Ablank }} \times 100
$$

Antiradical activity was expressed as $\mathrm{SC}_{50}$ (mg. $\left.\mathrm{L}^{-1}\right)$, defined as the concentration of test material required to cause a $50 \%$ decrease in initial DPPH absorbance.

\section{Antifungal activity \\ Preparation of the culture medium}

$11.5 \mathrm{~g}$ agar of yeast extract (Yeast extract AGAR) and $10 \mathrm{~g}$ of anhydrous glucose are mixed with $500 \mathrm{~mL}$ of distilled water for the preparation of culture medium. After sterilization and addition $5 \mathrm{~mL}$ of oxytetracycline $(0.1 \%)$, this medium was cast in limp of Petri dish $9 \mathrm{~cm}$ in diameter at a rate of $17 \mathrm{~mL}$.

\section{Detection of the moulds}

A quantity of vegetable weighed from gardening culture, fresh tomato fruits and banana leaves was diluted in sterile peptone water in order to detect fungi responsible of their deterioration. $30 \mathrm{~min}$ after homogenizing each sample, $0.1 \mathrm{~mL}$ of the inocula was spread out on the sterilized mould medium (Yeast Extract Glucose Agar: YEGA) and uniformly. The present limp was incubated at $25{ }^{\circ} \mathrm{C} \pm 1{ }^{\circ} \mathrm{C}$ five days awarded from day light.

\section{Transplantation and mycelial growth}

The moulds detected after examination and identification then, are transplanted (subcultured) using a disc of $6 \mathrm{~mm}$ in diameter which carries spores from the anamorph mould on the surface of Petri dish containing the former medium YEGA containing tested essential oils at different concentrations or no (positive control). In the same way, four dilutions of synthetic fungicide (tebuconazole, with a commercial name folicur $250 \mathrm{EW}$ and concentration of $\left.250 \mathrm{~g} . \mathrm{L}^{-1}\right)$ at respective concentration of 0.05 , $0.1,0.5$ and $1 \mathrm{ppm}$ had been prepared by successive dilutions of the commercial fungicide in sterile distilled water. The synthetic fungicide represents the control tester. The moulds subcultured were incubated at $25{ }^{\circ} \mathrm{C} \pm 1{ }^{\circ} \mathrm{C}$. The mycelial growth was appreciated every day by measuring the average of two perpendicular diameters passing by the middle of the disc, from the first day till the seventh one at, least 6 days (Khallil, 2001).

The antifungal activity was evaluated by the following equation (Chang et al., 2000):

$$
I=\left[1-\frac{d}{d e}\right] \times 100
$$

with $\boldsymbol{I}$ - antifungal index; $\boldsymbol{d}$ - diameter of growth of Petri dish treated out of essential

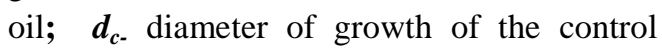
(witness) [Petri dish without essential oil ].

\section{Test of determination of the fongiostatic or fungicidal activity}

With the experimental concentrations where neither growth, nor germination was observed, the fungiostatic or fungicidal activity was tested. This test consisted in taking the mycelial disc not germinated at the end of the incubation of the Petri dish and reintroducing it in a new culture medium (former one) nine without natural extract. If the mycelial growth is always inhibited, the fungicidal activity of the natural extracts and in the contrary case, it's spoken about fongiostatic the activity. 
Antibacterial activity

Essential oil emulsion

$2 \mathrm{~mL}$ of Mueller Hinton broth added with $0.02 \mathrm{~g} / \mathrm{L}(\mathrm{w} / \mathrm{v})$ of phenol red were added $40 \mu \mathrm{L}$ of essential oil and 2 drops of Tween 80 had been introduced in an hemolyse test tube and homogenized.

\section{Preparation of bacteria suspensions}

This preparation was carried out from the three stocks of tested bacteria. A pure colony of each stock was suspended in $5 \mathrm{~mL}$ of Mueller Hinton broth. After incubation at $37{ }^{\circ} \mathrm{C}$ for 2 hours, we obtained $10^{6} \mathrm{CFU} / \mathrm{mL}$ corresponding to the scale 2 of McFarland standard.

\section{Determination of Minimal Inhibitory Concentration (MIC)}

The method used was reported by Yehouenou et al. (2010). $100 \mu \mathrm{L}$ of bubble Mueller Hinton broth containing of phenol red to $0.02 \mathrm{~g} / \mathrm{L}$ were distributed in all the 96 wells of microplate. $100 \mu \mathrm{L}$ of essential oil emulsion (initial solution) were added well of the first column except that of the second line and we carried out successive dilutions of reason 2 were carried out well by well till the $12^{\text {th }}$ one and the remaining aliquot $(100 \mu \mathrm{L})$ were rejected. $100 \mu \mathrm{L}$ of Mueller Hinton which not containing phenol red were introduced on the first well of the first columns and successive dilutions of reason 2 were carried out as before. All the wells of the second column received $100 \mu \mathrm{L}$ of bacteria suspension except the first line which represents the negative control and the second line, the positive control. The microplate one was finally covered with paper parafilm and was incubated at $37^{\circ} \mathrm{C}$ during approximately 18 hours.

\section{Antibiotic capacity of the extracts}

The antibiotic capacity of essential oil was in experiments in the following way:

Muller-Hinton Agar (MHA) prepared and sterilized is cast in limp of Petri Dish of diameter $90 \mathrm{~mm}$. The microbial suspension carried out starting from colonies isolated from Escherichia coli on the one hand and Staphylococcus aureus on the other hand is spread out on the surface of the MHA at a rate of $0.1 \mathrm{~mL}$ of the aforementioned suspension $(0.1 \mathrm{~mL}$ of the phase logarithmic curve of the bacterium to a density adjusted on scale 0.5 of McFarland corresponding to $\left.10^{8} \mathrm{ufc} / \mathrm{mL}\right)$. In the center of the Petri Dish sown using one or the other of the stocks, one deposits, for $E$ coli, the discs of antibiotic of reference Chloramphenicol $(30 \mu \mathrm{g})$, Gentamycine (10 $\mu \mathrm{g})$, the Nalidixic acid $(30 \mu \mathrm{g})$ and Ceftriazone $(30 \mu \mathrm{g})$ on the one hand and for $S$. aureus the discs of antibiotics of reference Lyncomycine $(15 \mu \mathrm{g})$ Erythromycine and Tétracycline $(30 \mu \mathrm{g})$. Each Petri Dish of MHA more (stock) is sown of only one disc of antibiotic and investigate essential oil three times with the concentration corresponding to that of the antibiotic disc of reference. A witness (sterile disc of $6 \mathrm{~mm}$ of diameter) is also deposited on the Petri Dish in the same experimental conditions. The Petri Dish thus sown are incubated at $37{ }^{\circ} \mathrm{C} \pm 1{ }^{\circ} \mathrm{C}$ during 24 hours. The readings are made by measuring the diameters of the halos of incubation for each disc of reference and essential oil.

\section{Statistical analysis}

Data were subjected to analysis of variance (ANOVA). They were expressed as the mean \pm standard error of triplicate measurements; standard deviations did not exceed $5 \%$.

\section{RESULTS \\ Chemical composition}

The yield of the essential oil obtained by hydrodistillation of fresh seed of Syzygium aromaticum is $0.18 \%$. Twenty-one compounds representing (99.4\%) of Syzygium aromaticum oil was identified by GC/MS (Table 1). the majority being the oxygenated monoterpenes and sesquiterpene hydrocarbons : eugenol $(60,4 \%)$, trans $\beta$ caryophyllene $(24.0 \%)$ and eugenol acetate $(10.0 \%)$ and a lower concentration of $\gamma$-muurolène $(1.4 \%)$ and $\beta$-sesquiphellandrène $(1.7 \%)$. 


\section{Antiradical activity}

The determination of the concentration of antioxydant necessary to decrease DPPH radical concentration by $50 \%$ (so called SC50) give $10.3 \pm 0.5 \mathrm{mg} / \mathrm{L}$ for the essential oil and $1.60 \pm 0.08 \mathrm{mg} / \mathrm{L}$ for eugenol.

\section{Antifungal activity}

The antifungal activity of the essential oil of Syzigium aromaticum L. was evaluated and the following results were shown in Figure 1 . We observed $78 \%$ of inhibition rate after 2 days for concentrations $\geq 1 \mu \mathrm{L}$ of essential oil.

\section{Antimicrobial activity}

The results of the antimicrobial activity were reported in Table 2.

Table 1: Chemical composition of essential oil of seed of Syzygium aromaticum.

\begin{tabular}{|c|c|c|c|}
\hline RI* & Component & $\begin{array}{c}\text { Percent } \\
\text { Composition }\end{array}$ & $\begin{array}{c}\text { Identification } \\
\text { methods }\end{array}$ \\
\hline 831 & furfural & 0.2 & MS, RI \\
\hline 1370 & eugenol & 60.4 & GC, MS, RI \\
\hline 1423 & trans- $\beta$-caryophyllene & 24.0 & GC, MS, RI \\
\hline 1438 & $\beta$-duprezianene & 0.1 & MS, RI \\
\hline 1442 & $\alpha$-guaiene & 0.1 & MS, RI \\
\hline 1451 & (Z)- $\beta$-farnesene & 0.1 & MS, RI \\
\hline 1463 & $\alpha$-himachalene & 0.1 & MS, RI \\
\hline 1473 & $\alpha$-humulene & 0.1 & MS, RI \\
\hline 1494 & $\gamma$-muurolene & 1.4 & MS, RI \\
\hline 1514 & germacrene D & 0.1 & MS, RI \\
\hline 1517 & eugenol acetate & 10.0 & GC, MS, RI \\
\hline 1537 & $\beta$-sesquiphellandrene & 1.7 & MS, RI \\
\hline 1560 & $\delta$-cadinene & 0.2 & MS, RI \\
\hline 1569 & \multirow{2}{*}{$\begin{array}{l}10 \text {-epi- } \alpha \text {-cubebol } \\
\text { isolongifolanone }\end{array}$} & 0.1 & MS, RI \\
\hline 1616 & & 0.1 & MS, RI \\
\hline 1639 & davanol $\mathrm{D}_{2}$ (isomere 2 ) & 0.2 & MS, RI \\
\hline 1697 & davanol acetate & 0.1 & MS, RI \\
\hline 1708 & heptadecane & 0.1 & GC, MS, RI \\
\hline \multirow[t]{6}{*}{1724} & cedroxyde & 0.1 & MS, RI \\
\hline & Total identified & 99.4 & \\
\hline & Monoterpene hydrocarbons & 0.2 & \\
\hline & Oxygenated monoterpenes & 60.4 & \\
\hline & Sesquiterpene hydrocarbons & 38.1 & \\
\hline & Oxygenated sesquiterpene & 0.7 & \\
\hline
\end{tabular}

$\mathrm{RI}^{*}$, Retention index relative to $\mathrm{n}$-alkanes $\left(\mathrm{C}_{9}-\mathrm{C}_{20}\right)$ on a DB1 capillary column; $\mathrm{GC}$, identification was based on retention times of authentic compounds on a DB1 fused silica capillary column; MS, identification was based on computer matching of the mass spectra of peaks with NBS75K.L and NIST98.L libraries and published data (Adams, 2007; Joulain and König, 1998); RI, tentatively identified based on comparison of retention index of the compounds compared with published data (Adams, 2007; Joulain and König, 1998). 
Table 2: Antimicrobial activity (Minimal Inhibitory Concentration: MIC value, $\mathrm{mg} / \mathrm{mL}$ and Minimal Bactericide Concentration: $\mathrm{MBC}$ value, $\mathrm{mg} / \mathrm{mL}$ ) of essential oil of seed of Syzygium aromaticum.

\begin{tabular}{lcc}
\hline Microbial stock & $\begin{array}{c}\text { Minimal Inhibitory } \\
\text { Concentration } \\
\text { (MIC) }(\mathbf{m g} / \mathbf{m L})\end{array}$ & $\begin{array}{c}\text { Minimal Bactericide } \\
\text { Concentration }(\text { MBC) } \\
(\mathbf{m g} / \mathbf{m L})\end{array}$ \\
\hline Escherichia coli ATCC 25922 & $0.20 \pm 0.01$ & $3.12 \pm 0.16$ \\
Staphylococcus aureus ATCC 25923 & $0.025 \pm 0.002$ & $1.56 \pm 0.09$ \\
\hline
\end{tabular}

Table 3: Evaluation of the sensitivity of the microbial stocks tested with respect to antibiotics of reference and of the essential oil of Syzygium aromaticum.

\begin{tabular}{|c|c|c|c|c|c|c|c|}
\hline & \multicolumn{4}{|c|}{ E. coli (Diameter mm) } & \multicolumn{3}{|c|}{ S. aureus (Diameter $\mathbf{m m})$} \\
\hline & $\begin{array}{l}\text { Chloram- } \\
\text { phenicol }\end{array}$ & $\begin{array}{l}\text { Genta- } \\
\text { mycine }\end{array}$ & $\begin{array}{c}\text { Nalidixic } \\
\text { Acid }\end{array}$ & Ceftriazone & $\begin{array}{l}\text { Lynco- } \\
\text { mycine }\end{array}$ & $\begin{array}{l}\text { Erythro- } \\
\text { mycine }\end{array}$ & Tetracycline \\
\hline & $18.0 \pm 0.7$ & $18.0 \pm 0.7$ & $00.0 \pm 0.0$ & $21.0 \pm 0.8$ & $24.0 \pm 0.9$ & $24.0 \pm 0.9$ & $30.0 \pm 1.2$ \\
\hline E.O & $20.0 \pm 0.8$ & $12.5 \pm 0.5$ & $13.0 \pm 0.6$ & $00.0 \pm 0.0$ & $18.0 \pm 0,9$ & $30.0 \pm 1.2$ & $00.0 \pm 0.0$ \\
\hline
\end{tabular}

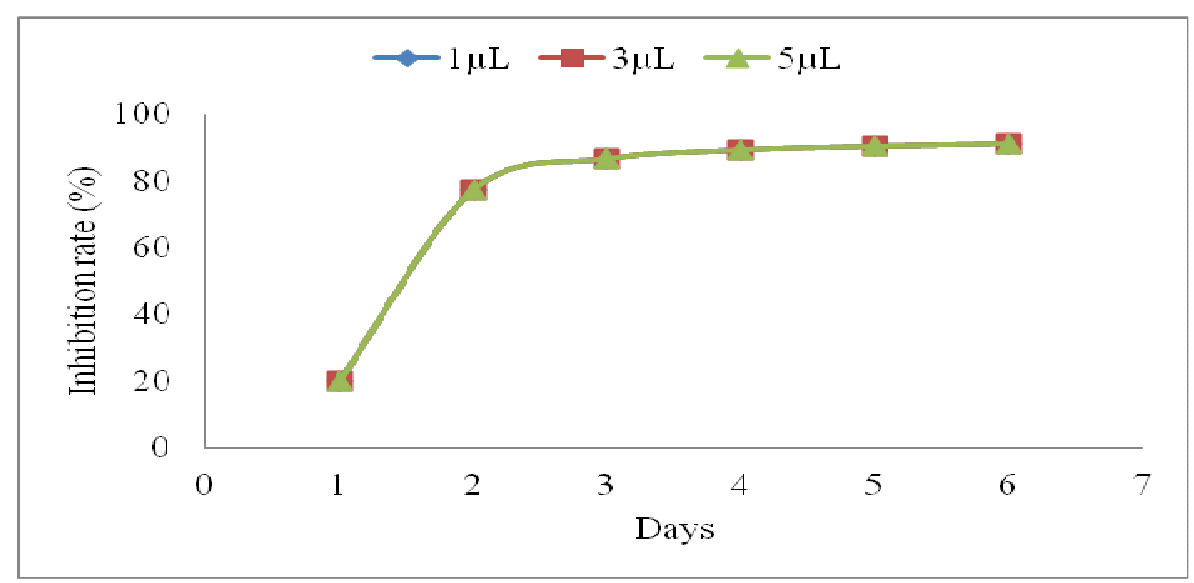

Figure 1: Action of the essential oil of seed of Syzigium aromaticum L. with various concentrations on the mycelial growth of Aspergillus parasiticus.

\section{DISCUSSION}

\section{Chemical composition}

Globally, the essential oil was dominated by aromatic structures p-menthane and was characterized by high percentage of eugenol $(60.4 \%)$ accompanied by trans- $\beta$ caryophyllene $(24.0 \%)$. This chemical profile corresponds to the one previously described by Politeo et al. (2010) for the variety of $S$. aromaticum identified in Croatia.

\section{Antiradical activity}

Significant free radical scavenging activity was observed for the essential oil; they were compared to that of the commercial antioxidant eugenol, which is widely used as a reference. 
The essential oil was less active, compared to its major constituent eugenol. This essential oil is also less active than that obtained by Politeo et al. (2010).

\section{Antifungal activity}

We noticed a progressive increase in ratio reduction (antifungal capacity) going from 20 to $91.11 \%$ during the 6 days with the three concentrations $(1 \mu \mathrm{L}, 3 \mu \mathrm{L}, 5 \mu \mathrm{L})$ of essential oil of Syzigium aromaticum L. tested (Figure 1).

The essential oil of seed of Syzigium aromaticum L. is most active against Aspergillus parasiticus, it showed a total inhibition of the mycelial growth (fungicidal) to a higher concentration $\geq 1 \mu \mathrm{L}$.

After having reintroduced the mycelial disc of the Petri dish having for concentration $1 \mu \mathrm{L}$ essential oil in a culture medium nine without natural extract, we noted that this essential oil carried on a fungicidal activity against Aspergillus parasiticus.

This activity is probably due to the presence of the majority compound (eugenol) or has a synergy between the majority compound and the minority compounds.

\section{Antimicrobial activity}

The essential oil of the seed of Syzygium aromaticum almost has an antimicrobial activity very interesting against Staphylococcus aureus ATCC 25923 and Escherchia coli ATCC 25922. MIC $=(0.025$ $\pm 0.002) \mathrm{mg} / \mathrm{mL}$ and $(0.20 \pm 0.01) \mathrm{mg} / \mathrm{mL}$ respectively (Table 2). In spite of a lack of antibiotic capacity (theoretically calculated) the Minimal Inhibitory Concentration (MIC) and the Minimal Bactericide Concentration (MBC) determined this essential oil showed a strong antimicrobial activity.

\section{Antibiotic capacity of the extracts}

The averages of the diameters of the halos of incubation measured in $\mathrm{mm}$ are consigned in the Table 3. These results show that $E$ coli ATCC 25922 is very sensitive to Chloramphenicol, Gentamycine and Ceftriazone, but resistant to Nalidixic acid. On the other hand, the essential oil of $S$. aromaticum presents an inhibiting action on the stock compared to Gentamicine in Chloramphenicol and the Nalidixic acid and is without action on the stock compared to Ceftriazone, whereas $S$. aureus is very sensitive to Lyncomycine, Erythromycine and Tetracycline, while the essential oil with an inhibiting activity on S. aureus compared to Lyncomycine and with Erythromycine and resists to Tetracycline.

\section{Conclusion}

The essential oil extracted from the seed of Syzygium aromaticum is rich in eugenol with a strong content (> $60.4 \%$ ). It detains a high bactericide activity against Escherichia coli and Staphylococcus aureus and antifungal against Aspergillus parasiticus. Somewhere it presents a very interesting antiradical activity. The essential oil shows compartmental antibiotic activities compared with antibiotic of reference with respect to the stocks tested $E$ coli and S. aureus.

\section{REFERENCES}

Adams RP. 2007. Identification of Essential Oil Components by Gas Chromatography/Mass Spectrometry (4th edn). Allured Publishing Corporation, Carol Stream: Illinois, USA.

Alitonou G, Avlessi F, Sohounhloue DCK, Bessiere JM, Menut C. 2010. Chemical and biological investigation on volatile constituents of Pentadesma butyracea sabin (Clusiaceae) from Benin. J. Essent. Oil Res., 22: 138-140.

Avlessi F, Alitonou G, Sohounhloue DK, Menut C, Bessière JM. 2005. Aromatic plants of tropical West Africa. Part XIV. Chemical and biological investigation of Lippia multiflora Mold. essential oil from Benin. J. Essent. Oil Res., 17: 405-407.

Baratta MT, Dorman HJD, Deans SG, Figueiredo AC, Barroso JG, Ruberto G. 1998. Antimicrobial and antioxidant properties of some commercial essential oils. Flavour Frag. J., 13: 235-244. 
Beuchat LR. 2000. Control of foodborne pathogens and spoilage microorganisms by naturally occurring antimicrobials. In Microbial Food Contamination, Wilson CL, Droby S (eds). CRC Press: Boca Raton, FL; 149-169.

Cai L, Wu CD. 1996. Compounds from Syzygium aromaticum possessing growth inhibitory activity against oral pathogens. J. Nat. Prod., 59: 987-990.

Chami F, Chami N, Bennis S, Bouchikhi T, Remmal A. 2005. Oregano and clove essential oils induce surface alteration of Saccharomyces cerevisiae. Phytother. Res., 19: 405-408.

Chang ST, Wang SY, Wu CL, Chen PF, Kuo YH. 2000. Comparison of the antifungal activity of cadinane skeletal sesquiterpenoids from Taiwania (Taiwania cryptomerioides Hayata) heartwood. Holzforschung, 54: 241-245.

Dorman HJD, Surai P, Deans SG. 2000. In vitro antioxidant activity of anumber of plant essential oils and phytoconstituents. J. Essent. Oil Res., 12: 241-248.

Friedman M, Henika PR, Mandrell RE. 2002. Bactericidal activities of plant essential oils and some of their isolated constituents against Campylobacter jejuni, Escherichia coli, Listeria monocytogenes, and Salmonella enteric. J. Food. Prot., 65: 1545-1560.

Gayoso CW, Lima EO, Oliveira VT, Pereira FO, Souza EL, Lima IO, Navarro DF. 2005. Sensitivity of fungi isolated onychomycosis to Eugenia cariophyllata essential oil and eugenol. Fitoterapia. 76: 247-249.

Joulain D, König WA. 1998. The Atlas of Spectral Data Sesquiterpenes Hydrocarbons. E. B. Verlag: Hamburg.

Kalemba D, Kunicka A. 2003. Antibacterial and antifungal properties of essential oils. Curr. Med. Chem., 10: 813-829.

Khallil AR. 2001. Phytofungitoxic properties in the aqueous extracts of some plants. Pakistan J. Biol. Sci., 4(4): 392-394.
Kim HM, Lee EH, Hong SH, Song HJ, Shin MK, Kim SH, Shin TY. 1998. Effect of Syzygium aromaticum extract on immediate hypersensitivity in rats. $J$. Ethnopharmacol., 60(2): 125-131.

Lavabre M. 1992. Aromaterapia: a Cura Pelos Oleos Essenciais. Ed. Bertrand Brasil: Rio de Janeiro.

Mellors A, Tappel AL. 1996. The inhibiton of mitochondrial peroxidation by ubiquinone and ubiquinol. J. Biol. Chem., 241: 4353-4356.

Miyazawa M, Hisama M. 2001. Suppression of chemical mutagen induced SOS response by alkylphenols from clove (Syzygium aromaticum) in Salmonella typhymurium TA1535/pSK1002 umu test. J. Agric. Food. Chem., 49: 4019-4025.

Murray BI. 2000. Plant essential oils for pest and disease management. Crop Protection., 19: 603-608.

Prashar A, Locke IC, Evans CS. 2006. Cytotoxicity of clove (Syzygium aromaticum) oil and its major components to human skin cell. Cell Prolif., 39(4): 241-248.

Politeo O, Jukic M, Milos M. 2010. Comparison of chemical composition and antioxidant activity of glycosidically bound and free volatiles from clove (Eugenia caryophyllata Thunb.). Journal of Food Biochemistry, 34: 129-141.

Sellan W. 2002. O'Leos que Curam. O Poder da Aromaterapia. Editora Record.

Yehouenou B, Wotto DV, Sessou PH, Noudogbessi JP, Sohounhloue DCK. 2010. Chemical study and antimicrobial activities of volatile extracts from fresh leaves of Crassocephalum rubens (Juss and Jack.) S. More against food borne pathogens. Scientific Study and Research, 11(3): 343-351.

Zheng GQ, Kenney PM, Lam LKT. 1992. Sesquiterpenes from clove (Eugenia caryophyllata). J. Nat. Prod., 55: 9991003. 